\title{
Insult to the Personal Dignity
}

\author{
Aleks Prifti \\ Lecturer, Department of Justice, Ismail Qemali University of Vlora \\ E-mail: aleks2prifti@gmail.com
}

\section{Doi:10.5901/mjss.2014.v5n2p121}

\begin{abstract}
The During the extended transition period, Albania has spent more than two decades, consumption of the crime of aggression (as well as that of defamation) was never deleted from the map of counter-legitimacy. Meanwhile, the highest legislative body of the State adopted five years ago some changes to the Criminal Code, specifically changing article 119 (insult), Section 120 (defamation) and some other provisions relating to such offenses. This measure was accompanied by amendments to the Civil Code, be specified and trying to improve, Institute of moral damage, which presupposes to guarantee sufficient protection over the dignity and reputation of the individual. Precisely, the subtle aspects that brings this argument, the judged necessary, making this essay to an analysis, even diagonally, of the main elements of the offense in general and that through mass media in particular, by explaining some key words such as object protected by norms, active entity; passive entity; difference between fact and their assessment of legitimate reasons to justify the act of defamation, the right to information through the media and the right of honor; Reflections on changes legal punishment for the offense of insult.
\end{abstract}

Keywords: insult, active entity; passive entity,insult,personal dingnity;

\section{Introduction}

During the fast changing socio-economic system in Albania of the early of 90s of last century the first instruments of international law which was promoted and was ratified were the Universal Declaration of Human Rights human (1948), as well as the International Covenant on Civil and Political Rights (1966). One of the main reasons that led the Albanian public enthusiastically welcomed the acceptance of these documents it is estimated the reference to respect 'immanent human dignity' a term that in the West for several consecutive decades, has become the basic category of normative instruments international law as in the gobal both in regional and state. Inspiring influence of this term, opened in Albania, (closed for four decades from the communist system), opportunities for connecting such a basic category to the protection of human rights and freedoms, semantic and functional identity of which is not covered by this document.

Meanwhile he reported the topicality of this issue with the fact that here, as in other countries with dictatorial government, there have been numerous and shocking violations of these rights. On the basis of comprehensive changes starting in Albania, at the end of the last century, seemed reasonable, substantial and immediate demand for its admission to the Council of Europe, with no serious reservation regarding the adoption of the European Convention for the Protection Rights and Fundamental Freedoms. In this context, the Constitution of the Republic of Albania (1998), who resolved the only obstacle to the ratification of the ECHR, thus ensuring the right to life ${ }^{1}$ issue of 'human dignity' has spread in a line and a plane with modern features of the state and its main features. ${ }^{2}$

For implementation of this Basic Law, as well as several other international instruments (Convention on the Elimination of All Forms of Discrimination against Women (1979), Convention on the Elimination of All Forms of Intolerance and of Discrimination that rely on religion or conviction (1981), the Convention against Torture and Other Forms of Cruel, Inhuman and Degrading Treatment or Punishment (1984), Convention on the Rights of the Child (1989), etc., 'dignity' has a legal definition of values, which served to develop the Criminal Code of the Republic of Albania'the content of some offenses that violate personal dignity, as insult (Article 119), defamation (Article 120), beatings, physical violence (Article 90), etc..

\footnotetext{
${ }^{1}$ The Constitution of the Republic of Albania, Article 21

${ }^{2}$ Article 3 of the Constitution of the Republic of Albania: "The independence of the state and its territorial integrity, human dignity, rights and freedoms ... are the foundation of this country, which has the duty to respect and to 'protect'

${ }^{3}$ Article 1/bi Penal Code states: "The criminal legislation of the Republic of Albania has a duty to protect ... human dignity, rights and freedoms ..."
} 
However, during the extended transition period that has elapsed Albania for more than two decades, consumption of these crimes were never deleted from the map of antilegitimacy, while criminal penalties against them have been almost nonexistent. Such a trend was added even more surprisingly, after the Parliament passed in the year (2008) some changes to the Criminal Code, concretely to change the Article 119 (insult), Section 120 (defamation) and some other articles related to 'them. Proposing these changes then joined a report of the Council of Ministers, in which we read: "For an effective political democracy and respect for human rights, freedom of expression is not only important in itself, but it also plays a key role in the protection of other human rights. No free country, there is no democracy without a broad guarantee of the right to freedom of expression, guaranteed it through legal instruments of the rule of law".4

\section{The Object Protected by the Legal Provision}

Article 119 of the Criminal Code of the Republic of Albania provides that: "the deliberate insult a person constitutes a criminal offense and is punishable by fine or imprisonment up to six months. If the same act, committed to the detriment of some persons or more than once, constitutes a criminal offense and is punishable by fine or imprisonment up to one year. "So, the object protected by this legal provision is honor and personal dignity (Elezi, 2007: pp. 163). As noted, the Code expressly mentions only the term 'dignity'.

But, however, respect the honor, which is the object of protecting the crime of aggression is part of the dignity, based and derived precisely from him. Here is the place to specify the real object of this work, which is not a "sense of personal dignity", according to Albanian doctrine, ${ }^{5}$ but the honor of the person. Because feeling is something subjective, while the right is intended to protect the real value of a person and not as someone perceives (Stojani, 2007).

While dignity is more general object, because the offenses violate the privacy of the person ${ }^{6}$ of sexual crimes ${ }^{7}$. So, with 'honor' should understand complex circumstances of which depends on an individual's social value (Mantovani, 2005: pg. 185). More precisely, the "honor" to be understood all the moral virtues (reliability, loyalty, etc..), Intellectual (intelligence, education, schooling, etc..), Physical (health, etc..) And other features that characterize an individual's qualities the living environment (Antolisei, 1999:pg. 190 ), which according to the definition interpersonal: "Honor is respectful relationship with other people respect which stems from human dignity and forms his integrity as a person "8.

In this perspective 'honor' can be branches and be seen in two views: subjective and objective. On the subjective side the concept of 'honor', can call feeling and evaluation of the individual about his abilities, concretely personal feelings about the value to society; by objective, "honor" must be analyzed and evaluated in terms of the judgment of others reflect on individuals and it is on the consideration that the individual enjoys the public, then the reputation that a person has in his environment. As the sense of personal capability assessment and reputation could be harmed or put at risk. This can happen when an individual attributes another individual unfair quality. Such a behavior resulting passive subject insulting provoking a moral pain. Also insult can destroy or reduce the respect and esteem which surrounds the offended individual.

The truth of the fact which is attributed to a person only this is not enough to avoid offending the character of an action. For example, it is not legitimate to say "thief" an individual who was convicted by a final judgment for the offense of theft. He also has the right to be respected and not to be subject to not necessary degradation. The truth of an expression excludes antilegality of a fact in the cases provided by law, under certain conditions, which we will examine further.

\subsection{Active subject}

\footnotetext{
${ }^{4}$ Decision of the Council of Ministers No. 262, dated 05.04.2007 for proposing a bill "On Amendments to the Law No. 7895, dated 27.1.1995, the Criminal Code of the Republic of Albania, change", follow Assembly, on 09.05.2007, no. protocol. 1713/1

${ }^{5}$ Commentar of Criminal Code of Socialist Republice of Albania, year 1977, pp. 453; Journal "Drejtësia Popullore", Nr.3/1982; Commentar of Criminal Code of Socialist Republice of Albania, Special Part,, Vol I, Tirana 1964, pp. 186

${ }^{6}$ Article 121 of the Criminal Code, "Violation of privacy" Article 122: "The proliferation of personal secrets" Article 123: "Preventing or violation of the privacy of correspondence"

${ }^{7}$ Nenet 100-108 të Kodit Penal

${ }^{8}$ E.A. Wolff ZStW 81, 886 ff.; Schoenke/Schroeder/Leckner Rn.1; SK-Rudolphi Rn.5, Goessel BT 348; Maurach-Schroeder-Maiwald BT/1,8 § 24 Rn.5 Otto BT § 31/2; ders. Schwinge-FS 71 ff.; Kiehl [1986], 164 ff.; Koestlin [1858], 1-7; Ignor [1995], 174 ff.; LK-Herdegen Rn. 9-17; Tenckhoff [1974], 127, 174
} 
Active subject of the work at issue can be anyone: it is a criminal offense called ordinary ${ }^{9}$

It may be active subject a legal person who is criminally responsible for an offense that may be realized by its organs.

The question arises: Can there be criminal liability of a person drunk on alcohol? The answer should be negative, drunk person who offends can not be punished for the offense at issue, since the time of the offense is not critical and logical skills to assess how offensive words and gestures.

\subsection{Passive subject}

Passive subject namely the subject offended by the offender can be anyone. I can not speak for insulting when it comes from himself insulted. However, if the himself offender during telling the insulting fact story, submit other people criminal liability is inevitable. For example, $X$ indicates the realization of some obscene gestures made by him with a third. In principle may be subject to liability, even a minor or a mentally incapable. Even these subjects u need recognized an honor and a personal dignity within certain limits. There is punishable offense a minor correction to an activity, which (for that age) can not realize. In my opinion, insulting a disabled person should be specified as follows: Can not insulted disabled by telling facts that have realized because of disability on the contrary punishable offense offense is for facts performed by the disabled before he lost his mental ability (Stojani, 2007).

In this sequence of thoughts should be justified even in the case of a deaf or the person who sleeps at the time of insult. In these cases have shifted attentions to the ability or inability of the offender to act offended if possible or inability to act accomplished. One of the characteristic elements of the offense of insult is perceived insult. In other words, to realize the offense at issue is necessary for expression or enter offensive gesture perceptual sphere namely in the sphere of knowledge of another individual who must feel like such.

Regarding subjects without honor that is those persons public opinion or the law itself considers socially degraded and without good reputation even for these no offense because although the true basis can not be tolerated. Italian jurisprudence in these cases has emphasized that "even a compromised reputation may be subject to further violations"10. Thus, offensive, is the news that a subject who is on trial, or is judged to some offenses, somewhat realized other offenses ${ }^{11}$.

Agree with the doctrine of the Albanian criminal law, for which offense can be done in the absence of the injured (Elezi, 2007:pp.163 ). However, it should be determined that the offense can be configured only when the offense is directed to a specific person. As a result, we can not talk to insult, when it is not possible to identify a subject, for whom the offense.

However, the configuration of a criminal offense that is not necessary, explicitly setting, the name of an individual. Believe to be sufficient for the individual, through the story of some elements, directly or indirectly, of any type, can be identified with clarity and ease of the person who is in the presence of aggression.

\section{The Difference between Fact and His Assessment}

On the objective side, offense committed orally or in writing, by using of insulting or demeaning words. Materially, reputational offended should not be understood as damage, but as aggression, namely as a threat, since the use of insulting words or gestures can bring an effective damage. So the offense of insult should set an offense that endangers therefore act as the object that endangers protected from the norm.

The fact can also be done by telephone, telegraph, Internet, through writings, sketches or vignettes directed offended person.

\footnotetext{
${ }^{9}$ On the difference of ordinary crimes ( or general ) and special offenses ( or set) See F. Ramacci, Corso di DIRITTO offense, II ed ., Turin , 2001 , pg . 540 ss. Called general offenses all acts that can be performed by anyone, ie works that do not require a speciifike quality of the person realizes. For example, the crime of murder can be accomplished by any man. Offense referred particular those actions that can be performed only by an entity designated by the legislator. For example, the crime of killing the baby, provided for in Article 81, can be accomplished only by the child's mother. The offense of passive bribery of judges, prosecutors and other justice officials, provided by Article 319 / a, can be realized only by those entities. Well , only if the judge, prosecutor or other justice officials seek or receive improper benefits etc. ., Can be accomplished offenses in question. If these requests are made by another entity, for example , no justice officials , can not be applied article 319 / a, but other articles .
}

10 Ita, Cass. Pen. 22.09.2004, L., CED 230574

11 Ita, Cass. Pen., 08.04.2003, L., Riv. It. Dir. Proc. Pen. 2005, pg. 471 
Materially, one of the problems is insulting relativity. Offensive value of an expression, a gesture or an act is rather relative, changing significantly in function of time, place and rethanava. Just to give an example: the epithet "Ballist" in a particular historical moment in our country has been a valuable offensive and now identifies members of a political party. On the other hand the word "communist", which for decades and in certain circumstances has been a valuable distraction, now considered by the public as offensive because it is inconsistent with democratic values present. So it is clear than changing the value and weight of words for example, when expressed in a serious meeting, or when expressed on a cheery environment, as can be a humor show. Value of an expression deemed offensive under the stage and the social ladder is part of the individual to whom it is addressed. Consequently, the attribution of ignorance, about a discipline can be considered an insult to the person who should know discipline because of his profession, but not for others. For example, the journalist who says "incompetent" politician, because he does not understand the policy, making insults against the latter, on the contrary, the same expression can not have the same value offensive against a citizen of the apostrophized the same expression.

However it should be noted that there is a minimum honor and dignity that belongs to every person regardless the degree of education, cculturation, etc. Consequently minimum honor and dignity is common to every individual, for the mere fact of being human. Above this minimum offensive character depends on the social position of the offenders.

Typical behavior usually carried out in an oral (verbal insults), but can also be done by material acts as for example, gestures slanderous, insulting melody, spitting, wall painting, photography, and all acts or facts express contempt insulting sense of honor and personal dignity (Antolisei, 1999: pg. 200 ).

Meanwhile, the offense of insult, can be carried out through a physical act, which constitutes direct action exerted on the body of the person affected (for example, spitting in his face dishonorable cutting the hair of someone kicking, nibble 's beard, etc.), through which the author also expresses his humiliation and lack of respect ${ }^{12}$. One point of view, argues, under which it would suffice any physical action directed or given to another body and it would not be necessary touching, contact ${ }^{13}$.

For example, when a flash to the other's face does not touch his face; Proponents of this view argue that the reason for the prediction of such a form of insult is not actual violation of bodily integrity, but the expression of a particularly degrading humiliation for the person, then that action is enough to have such an understanding objectively.

The opposite view of the above thesis rejects the argument that "through a physical act" includes not only intellectual humiliation of another (no action), but also the additional effect of degrading the victim through the body and, therefore, to consumption should act consequence was the physical contact.

Thus, the measurement of the crack or the start of offensive attack, which goes to waste, do not have an attempt insult (physical) undeniably, but with an insulting consumed.

The difference lies in the evaluation; this offense does not qualify as the most physical, but simple formal insult. Even the so-called "sexual offense" cannot be a priori, nor common insult, or by a physical act. Also not every kind of immoral action, the body of another, there is said to be the physical insult as long as he is not in a particularly humiliating to express to humiliate the victim of copyright. If physical mistreatment have consumed the crime of beating or physical insult or both together this poses a problem the answer to which will be needed and to rely on the objective circumstances of the specific case, namely events and causes its participating individuals and their relationships and environment. It seems reasonable that the insulation acts, can be configured by the rejection.

However should precisely state that the refusal offense may be only in those cases where the law requires a positive attitude by subject ${ }^{14}$. So do not cause offense the citizen who refuses to give hand politician, because there is no a genuine liability provided by law to the contrary the elements of the offense meets the behavior of the military who greeted his superior appropriate gesture (F. Mantovani, 2005: pg. 227).

\section{Legitimate Reasons Justifying the Act of Insult}

Justifiable causes, justifying insults exercise of a right, a duty and fulfillment, in my opinion, the necessary protection. Regarding to the latter, it seems reasonable to protect a personal right, or a third, of the current offense and unfair. For

12 Deutschlands Bundeslandsgericht, "NJW" 1951, pg. 368; Rechtssprechung des Deutschlands Bundeslandsgerichts in Strafsachen 35, 77; Blei (Sonder Teil), 108; Dreher/Troendle, Satz. 12; Herdeger Kommentar, Satz.15; Maurach/Schroeder/Maiwald (Sonder Teil), 1/8 Satz.14; SK-Rudolphi par.21

${ }^{13}$ Frank Erläuterungen IV; Geppert Jura, 1983, pg. 588; Lackner/Kuehl, Satz.13; Schoenke/Schroeder/Lenckner, Satz 18

${ }^{14}$ For the change between active behavior and what omisive see: The. Elezi - S. Kaçupi - M. Haxhia, Komentari i Kodit Penal të Republikës së Shqipërisë, Tiranë, 2006, fq. 95. F. Ramacci, Corso, cit., pg. 301 
example, no insult he committed to in order to avoid theft, before consuming it calls "thief", "thief". Regarding the performance of duty may bring a number of occasions that exclude criminal liability for insult. For example:

a. duty to citizens or police forces, who report a crime;

b. duty to witnesses and experts, to tell the truth in civil or criminal proceedings.

c. duty to give criminal certificate;

d. duty to prosecute, those who have carried the offense etc.

As cases fulfillment of duty to eliminate anti-legality of insulation can mention:

a. collection and distribution of commercial information;

b. Warner's of fulfillment of duties in family, work, education, etc.

However, the possibility of a superior or guardian, to criticize the subordinate or person under custody must be understood within certain limits, exactly within the limits of necessity and proportion. Italian jurisprudence has emphasized that there is fulfillment of duty (jus corrigendi), the words used (for example, by the teacher, or parent) are vulgar and offensive level, excluding any corrective or educational function ${ }^{15}$. Insulation act is realized by the employer not the employee who rebuked for their work, but for his personal qualities showing contempt for the author of conduct, which are given negative qualities that have no connection with the performed work.

\section{The Right to be Informed through the Media and the Right of Honor}

The right to be informed and to make critical elements that justifies defamation through the press. They find some foundation in constitutional provisions that guarantee freedom of expression, information and press. ${ }^{16}$ From the content of these provisions, certain principles can be drawn: there is a freedom to information, freedom of information and freedom of information. Suffice to ponder a bit and we will discover that freedom of information, freedom arises from being informed, which should be understood as the freedom to receive possible information; Thus freedom of information fed by freedom of information and vice versa. However, freedom of information by the press and she thought are not absolute and unconditional. They find a limit on buildings and other interests equally guaranteed by the Constitution and the European Convention on Human Rights ${ }^{17}$.

Among these objects and interest include the inviolable human rights among which after the right to life, the right to honor highlights (along with realizing the right to dignity and reputation) that is protected by Articles 119 and 120 of the Criminal Code. In this bilancim objects it is clear that freedom of opinion and information can not sacrifice the right to maintain the honor, reputation, prestige, dignity, protect, and classified as inviolable the other rate constitutional and international law.

In this context, it is clear that the right to development and publication of news (ie the right to be informed) as well as the right to make critical (derivative of the right to freedom of thought) together constitute a guaranteed fair public subjective. As such its exercise of that illegality makes an affront to drop down to this right ${ }^{18}$ (Bozheku, 2010). The truth is the logical limit for the right of development and publication of information (Musco, 1979, pg. 117). It should be regarded as an essential condition for correct formation of public opinion to justify the superiority of the right of informing compared with interests that occasionally encounter.

Logical reasoning that should enlighten the judge in assessing an article with offensive content is primarily true of information and interpretation. The latter were subject to societal needs for information and should be accurate and objective; can not be accepted without a real objective basis.

The question arises: What happens if the active subject (journalist) falls into error (error fact) about the truth of the news? Can the author of a paper to appeal to the presumed truth? On the purely systematic, as it is known, the error on one of the elements of the offense themolorë precludes punishment for lack of a subjective element namely the lack of

\footnotetext{
15 It. Cass. Pen., 03.11.1994, Fioravanti, CED 20441, in Riv. pen., 1995, f. 1184; It., Cass. Pen. 28.10.1994, Silvestri, CED, 200438, in Riv. pen., 1995, pg. 1184

16 It. Cass. Pen., 03.11.1994, Fioravanti, CED 20441, in Riv. pen., 1995, f. 1184; It., Cass. Pen. 28.10.1994, Silvestri, CED, 200438, in Riv. pen., 1995, pg. 1184

${ }^{17}$ Articles 9 and 10 of the ECHR

${ }^{18}$ It must be said that the right to information and right to criticize the present deep conceptual difference: the right to inform its object the story in the press (media in general), the facts in the public interest, the right the criticism is right to give an opinion or an assessment of a fact. However, this is not the place to make estimates between differences between these rights. For a more detailed overview on the orientation of the Italian judiciary.
} 
intent ${ }^{19}$. Regarding error in the crime of aggression in my opinion this error can only come to the truth or falsehood of the news, but not in the public interest, or the correctness of telling, since in these cases, are forward an error, which falls on a legal norm, more precisely, on Articles 22 and 23 of the Constitution.

The error in these cases is not able to avoid the intent because (as it is known) error that falls on the recognition of a law does not preclude criminal liability, even though the error falls on a non-penal law ${ }^{20}$. Evaluation of error on the truth of the news should be based on factual elements, because it is invalid, subjective assessment of the truth of the news by the author. A journalist who brings no really news, to prove the existence of an error (ie, the truth of presumed) not enough his personal conviction of the truth, but must prove that fell into error about the fact - subject the truth.

But not only that, Article 21 of the Criminal Code of the Republic of Albania states that: "... there is no criminal responsibility the person who acts to exercise a right or fulfill the tasks assigned by law ..." From this article, it is clear that, not having criminal liability, should the journalist to realize the right to inform - stated in the Constitution and the ECHR - in accordance with the obligations arising upon the 'in based on its quality as a journalist. So, journalist exercising the right to information is not enough just to implement it but it is necessary that he be brought into compliance with the obligations arising as a professional and passionate in this field.

Consequently, an obligation arises on the journalist to verify strictly the truth of news and information sources in general. It is the duty of journalists to analyze, investigate and evaluate the news gets. It is not enough simply to bring the news desk but that news must be certified as real by concrete investigation. Therefore, journalists must show evidence objectively true -, taking the utmost care in the selection of information sources by selecting the maximum attention ton credibility of news that gets occasionally and making a deep control as news, as well as resources.

Only after these checks if there continues to be discordance between the facts and the facts indicated occurred the journalist can be appealed to the principle of error on the truth of the news on the contrary, the reporter should respond to insults. If it proves the correctness of these parameters based on, his behavior cannot be considered a punishable. ${ }^{21}$

According to Wenzel (1968), the second condition that legitimizes the exercise of the right to chronicle the news is public interest, which should be understood as social interest on the recognition of news - subject to publication. For example, public interest has news relating to the personal life of a politician, if that influence the development of his political activity. So, if the politician frequents personages suspected of involvement in criminal activities, the news is in the public interest.

In my opinion is not in the public interest, the news about the private life of a public person, so make insults. However, if it comes to an individual should have, depending on the function it performs a high morality, then the news published on the last spark public interest, and therefore their publication does not constitute an offense. For example, a priest for his institutional role should present a high morality, therefore the publication of news - the truth - on some moral behavior of the priest have sufficient interest to make publishing news not offensive, or better say they respect the parameters required by the right information to make not fact not- illegal.

The third, to be followed by the journalist for a correct development of the right to information is the way of expression. Constitute the offense all those expressions that have no connection with the subject of the story, and that they constitute a threat to open the dignity of the person - the subject of the article. For example, in a court chronicle which speaks for an investigation on a criminal organization expression as superficiality prosecutor, disability investigative bodies, etc., should be considered offensive because the story's object is to provide judicial character news. Estimates or quotes derogatory constitute an offense that hasent connection with news.

\footnotetext{
${ }^{19}$ Aberration theory, based on the principle, according to which, if that active subject of the offense, falsely imagine, because aberration, an element of the offense, not to speak of deliberate, because the moment volitiv is misleading because of the error, which has fallen author. For example, there may be liable for intentionally killing hunter who falsely imagine the existence of an animal after bush and fails to recognize that it was not animals, but human. To put the argument see:I. Elezi - S. Kaçupi - M. Haxhia, Komentari, cit. pp. 129; also you can see F. F. Ramacci, Corso, cit., pg. 349 etc.

20 Problems error on non-criminal law, is still one of the arguments discussed in the doctrine. In my opinion, no error on criminal law, can not be considered fit to avoid the intent of the offense, and this for two reasons: first, it is the duty of all citizens to know the laws that are published in the Official Journal and are widely consultable by anyone, therefore no one can appeal to ignorance of the law, secondly, Article 4 of the Criminal Code reveals the principle "... Ignorantia legis non exscusat ...". The aim is to avoid rate for individuals appealed to ignorance of the law to avoid penalties. This reasoning should apply to those laws, even though no criminal laws, are not applied (because they are not recognized by the author) would bring the effect of not applying criminal law.

21 In my opinion constitute an insult to the dignity and honor those reconstructions of events, which avoids mention of the circumstances leading to the orientation and made public. It comes to journalistic chronicler, although that really give news are constructed in such a way as to create public opinion in a certain image positive or negative event or some aspects o its protagonists.
} 
It is another critical article which openly praises and criticizes concrete elements is based, investigative activity. In this case entering a different theme which is that of the right of criticism, argument responding or be subject to other interpretive criteria.

\section{Conclusion - Reflections on Legal Changes Conviction for the Offense of Insult}

To help the analysis, we can make a parallel with the criminal offense of beating (Article 90 of the Criminal Code). It insults cannot call anything except, spiritual "beating". Not to say that in terms of social danger as one of the basic criteria to determine whether a harmful behavior would be classified a crime or not the offense is much worse than the beating. For the latter effects disappear with the passage of days, while the offense may remain for a lifetime; And yet easily beating and wounding, are not de-penalized by the Criminal Code, as was done with insult and defamation.

The object of such offenses is the legal relationship that protects human honor (sense of personal dignity (Elezi, 2002:pp.130). Honor is a man's value is recognized and accepted by other people (relationship of respect,-our note), which derives from the value of its dignity and integrity of its forms as a person"22. Integrity of the person, as a result of the relationship of recognition or acceptance by others, and indeed form the other individual objects (inviolability of life, health, etc..), But the concept of integrity is not limited to external elements mainly individual liberty. Freedom is based on a man's inner shaft, whose stability he just keeps being shown to others. So integrity understood in this way is not a status, which can be created entirely by the person, but that can be formed and maintained only through acceptance of others (inter-personality).

This report access by third parties, that requires very dignity of each, thus expresses a fundamental interpersonal relationship and social phenomenon rather than a random. Being such an interdependent relationship, the person proves the real harm when it denied him without recognition of the right. And, on the other hand, being a basic human relationship, violation of this recognition through insulation (as well as defamation) would constitute such a risk society, which fully justifies their inclusion as criminal, not the legitimate efforts their decriminalization.

With the sanction of law for social respect, criminal law provides the ability to protect coexistence among people, protection which if not guaranteed, would severely distort the base of a society ${ }^{23}$. However, having to do with an offense that is consumed mainly by the expression and articulation of its time, the possibility of preventing the infringement of a person affected by the institute of protection needed, is almost nonexistent.

Work becomes particularly dangerous when performed publicly through the mass media (form of publicly insulting). Because, unlike the insult made in the presence of a person where he is able to react instantly to person and only one person impairment (author), in this case it enables the creation of a negative opinion around public opinion independently from the injured person.

Given the unity of the objective side elements (with spreading falsehood) and aggravation of subjective side (bad faith, intent to distortion of public opinion and intention of infringing the honor through this misinformation), it is acceptable not only analization of defamation, but is not sufficient in the case of its consumption even just pull the Article 119 as lex generalis (since the object is the same, so in many jurisdictions considered as 'slanderous insult', whereas the term 'defamation' of use to designate the work offense the 'false charges ${ }^{24}$ ' and the only remnant of Article 120 as lex specialist.

So, honor and dignity of the person should be protected as much as freedom of expression; nasalization of the offense (as well as defamation) would imply a hierarchy of rights, which in principle is illegitimate. In defense of this gap, as the best way was found five years ago amendment to the Criminal Code's Article 119 and Article 120, lifting the type of imprisonment and leaving only effect of punishment by fine, the increased mass the latter, on the grounds that so will not be left without protection Albanian citizen from unfair attacks on his personality and reputation, because this measure will be intertwined with the changes that will be made to the Civil Code. Changes, which - as explained by their makers -, "specifying and improving moral damages institute would provide more than adequate protection of the individual dignity. ${ }^{25}$

${ }_{22}$ E.A. Wolff ZStW 81, 886 ff.; Schoenke/Schroeder/Leckner Rn.1; SK-Rudolphi Rn.5, Goessel BT 348; Maurach-Schroeder-Maiwald BT 1/8 § 24 Rn.5; Otto BT § 31/2; ders. Schwinge-FS 71 ff.; Kiehl [1986], 164 ff.; Koestlin [1858], 1-7; Ignor [1995], 174 ff;; LK-Herdegen Rn. 9-17; Tenckhoff [1974], 127, 174

${ }^{23}$ The Constitution of the Republic of Albania, Article 3

${ }^{24}$ Das österreichische Strafgesetzbuch, art. 297; Codice Penale della Republica d'Italia, art. 368

${ }^{25}$ Decision of the Council of Ministers no. 262, dated 05.04.2007 for proposing the draft law "On Amendments to the Law no. 7895, dated 27.1.1995, the Criminal Code of the Republic of Albania, as amended 
However, Article 3 of the Constitution of the Republic of Albania, among others, states that the protection and respect of human dignity (as of honor - part of it) constitutes the state. And, this definition implies that these represent good value as important legal and existential human life, their criminal defense that can not be compensated with a moral redress through civil punishment character, as has happened and is happening in Albania in recent years.

We recall that the system of law, the relevant criminal convictions declared to protect those values which are of importance among the fundamental and vital to the individual, society and state.

\section{References}

Antolisei, F., 1999: pg. 200 . Manuale di diritto penale,. p.s. I, XIII ed., Hrsg. Milano, : Milano, .

Antolisei, F., 1999:pg. 190 . Manuale di diritto penale, p.s. I,. XIII ed., Hrsg. Milano: Milano.

Bozheku, E., 2010. Verità del fatto narrato e verità putativa nell'esercizio del diritto di cronaca. Diritto\&Diritti,Rivista giuridca on-line, Januario(1), pp. 36-48.

Elezi, l., 2002:pp.130. E drejta penale (Pjesa e posaçme). 1 Hrsg. Tiranë : ShBLU, .

Elezi, l., 2007: pp. 163. E drejta penale (Pjesa e posaçme). I Hrsg. Tiranë : SHBLU.

Elezi, I., 2007:pp.163 . E drejta penale. I Hrsg. Tirana: SHBLU.

F. Mantovani, 2005: pg. 300. Diritto penale, p.s. I, Delitti contro la persona,. II ed., Hrsg. Padova, : Padova, .

Mantovani, F., 2005: pg. 185. Diritto penale, p.s. I, Delitti contro la persona. II Hrsg. Padova,: Padova.

Musco, E., 1979, pg. 117 . Onore formale ed onore reale come oggetto di tutela,. AA.VV. Tutela dell'onore e mezzi di comunicazione di massa, 1(1), pp. 115-127.

Stojani, L., 2007. Për fyerjen dhe shpifjen. "Tribunë Juridike", 2 (nr. 65), pp. 20-35.

Stojani, L., 2007. Argumente që i kundërvihen depanilizimit të veprës së fyerjes. "Jeta Juridike”,, Tiranë 2( 2), pp. 22-38.

\section{Legal References and Documents}

Cart of Unitetd Nations (1945)

Declarate ocer goals of ILO (1944)

Constitution of UNESCO (1945)

Universal Declarate of Human Rights 1948)

European Convention on Human Rights (1950)

International Pact on Economic Social and Culture Right (1966)

Pact Over Civil and Political Right (1966)

Convent on Eleminations of All Type of Discrimination Over Female (1979)

Declarate on elimination of all forms of intolerance and discrimination that is based on religion and conviction (1981)

Convention against Torture and Other Forms of Cruel, Inhuman and Degrading Treatmentor Punishment (1984)

Convention of Children Rights (1989)

constitution of Republic of Albania 1998

Criminal Code of Republic of Albania

Civil Code of Republic of Albania

Law "For some changes on law nr.7895, date 27.1.1995, Criminal Code of Republice of Albania, changed", 2008

Decision of Minister Council of republic of Albania, nr.262, date 04.05.2007

Criminal Code of Republic of Italia

Das österreichische Strafgesetzbuch 